\title{
Contraceptive practices and awareness of emergency contraception among Muslim women of urban slum of Raichur, Karnataka
}

\author{
Anju D. Ade ${ }^{1 *}$, Ramesh Patil $^{2}$ \\ ${ }^{1}$ Associate Professor, Department of Community Medicine, Navodaya Medical College, Raichur, Karnataka - 584103, \\ India, ${ }^{2}$ Assistant Professor (Statistics), Ashwini Medical College, Solapur - 413006, Maharashtra, India
}

Received: 22 November 2013

Accepted: 15 December 2013

\section{*Correspondence:}

Dr. Anju D. Ade,

E-mail: anju.ade@gmail.com

(C) 2014 Ade AD et al. This is an open-access article distributed under the terms of the Creative Commons Attribution Non-Commercial License, which permits unrestricted non-commercial use, distribution, and reproduction in any medium, provided the original work is properly cited.

\begin{abstract}
Background: According to NFHS-2005, prevalence of female sterilization is lowest among Muslims (21 percent). Many women prefer not to use contraception and continue childbearing until they have at least one son. Proper use of family planning methods is the key to preventing unplanned pregnancies. This study aimed to assess the contraceptive practices and awareness about emergency contraception among 82 married Muslim women in the reproductive age group.

Methods: A cross-sectional study was done in an urban slum area, Raichur where all the Muslim married women in the reproductive age group, attending OPD at UHC, during between August and September 2013 were interviewed using a pre-tested and pre-structured questionnaire. Privacy, anonymity and confidentiality were maintained throughout the process of this study.

Results: Out of total 82 Muslim ever married women, majority of them were literate, 63 (76.8\%). 50 (61.0\%) of women had family size less than or equal to $5.44(53.7 \%)$ were married at 16-19 years of age and $8(9.8 \%)$ women married between 12-15 years of age which is below legal age of marriage. Maximum total numbers of births were 3-4. Those who wanted male child had births between 5-6. Majority of women 34 (41.5\%) had a birth interval of 1 year and $19.5 \%$ women had no birth interval. 32 (39.0\%) women didn't use any contraceptive till they completed family. $71(86.5 \%)$ women were aware of all the methods of contraception. Majority of women $30(36.6 \%)$ received information from doctors. Only 11 (13.4\%) women were aware of Emergency Contraception.

Conclusions: Despite $76.8 \%$ literacy and $86.5 \%$ of awareness of the various methods of contraception, contraceptive practices were low among women. $32(39.0 \%)$ women didn't use any contraceptive till they completed family. There is a gap between awareness and practice. Awareness of emergency contraception is quite low among women (13.4\%). Emphasis has to be laid on delaying marriage and first pregnancy and education on planning and spacing children and reproductive contraceptive options, especially emergency contraception since all contraceptive methods can have potential failure; the use of emergency contraceptive of plays an important role in preventing unplanned pregnancies. There is a need to improve women's education about EC. The primary health care providers can play a major role in informing their patients about emergency contraception.
\end{abstract}

Keywords: Contraceptive practices, Knowledge, Emergency contraception, Muslim women

\section{INTRODUCTION}

India launched the National Family Welfare Programme in 1951 with the objective of reducing the birth rate to the extent necessary to stabilize the population, consistent with the requirements of the national economy. ${ }^{1}$ According to NFHS-2005; prevalence of female sterilization is lowest among Muslims (21 percent). Many women prefer not to use contraception and continue childbearing until they have at least one son. The 
proportion of women with two living children who do not want to have any more children is much lower for Muslim women (74\%) than for women in any other religious group. ${ }^{1}$

Proper use of family planning methods is the key to preventing unplanned pregnancies. Emergency contraception (EC) also called 'postcoital contraception' is a back-up contraception administered to women after unprotected sexual intercourse or contraceptive failure, so as to prevent unplanned pregnancy. However there are a number of barriers to the use of emergency contraceptive, namely the lack of knowledge, misconceptions, and unfavorable attitudes among women and health care providers, as well as inconvenient access to emergency contraceptive. $^{2}$

This study aimed to assess the contraceptive practices and awareness about emergency contraception among married Muslim women in the reproductive age group (18-45 years).

\section{METHODS}

This was a cross-sectional study among women attending OPD at Urban Health Centre, Ashapur Road (urban slum area), a field practice area of Department of community medicine, Navodaya Medical College, Raichur from August to September 2013. Women were administered pre-tested, pre-structured questionnaire. Data was collected on the following areas: socio-demographic characteristic, obstetric profile, use of contraceptive, source of information of contraceptives and awareness about emergency contraception. Ethical requirements of informed consent and confidentiality were ensured.

Data was entered into excel and analysed in SPSS.

\section{RESULTS}

\section{Socio-demographic data}

A total of 82 Muslim ever married women in a reproductive age (15-45 years) were interviewed. Mean age of the participants was 27.4 years. Majority of the respondents were in the age group of 18-22, 23-27 followed by 28-32 years. Literate rate was $76.8 \%$, while $42.7 \%$ had received primary and $28 \%$ secondary education. Most of them 58 (70.7\%) were house wives and those who were working outside were either housemaids or attenders. Majority $55(67.1 \%)$ of the respondents belonged to a nuclear family and had a per capita income per month of Rs. 200 to 1100 . Rest of them had a per capita income more than Rs.1100.Almost more than half of the participants $50(61.0 \%)$ had family size less than or equal to 5 , while remaining had family size more than $5.56 .1 \%$ of the respondents gave birth of first child during 17-20 years. In this study, majority of women had births up to 3-4. Those who wish to have male child had births between 5-6. Majority of women 34
(41.5\%) had a birth interval of 1 year and $19.5 \%$ women had no birth interval (Table 1). Family size of the women had no association with their literacy status (Table 2).

Table 1: Distribution of study group according to socio-demographic profile $(n=82)$.

\begin{tabular}{|c|c|c|}
\hline Category & No. & Percentage \\
\hline \multicolumn{3}{|l|}{$\begin{array}{l}\text { Age group } \\
\text { (years) }\end{array}$} \\
\hline $18-22$ & 20 & 24.4 \\
\hline $23-27$ & 27 & 32.9 \\
\hline $28-32$ & 18 & 22.0 \\
\hline $33-37$ & 8 & 9.8 \\
\hline $38-42$ & 9 & 11 \\
\hline \multicolumn{3}{|l|}{$\begin{array}{l}\text { Educational } \\
\text { status }\end{array}$} \\
\hline Illiterate & 19 & 23.2 \\
\hline Primary & 35 & 42.7 \\
\hline Secondary & 23 & 28.0 \\
\hline Graduate & 5 & 6.1 \\
\hline \multicolumn{3}{|l|}{ Occupation } \\
\hline Working & 24 & 29.3 \\
\hline Non-working & 58 & 70.7 \\
\hline \multicolumn{3}{|c|}{ Type of family } \\
\hline Nuclear & 55 & 67.1 \\
\hline Joint & 27 & 32.9 \\
\hline \multicolumn{3}{|l|}{$\begin{array}{l}\text { Family } \\
\text { size }\end{array}$} \\
\hline$\leq 5$ & 50 & 61.0 \\
\hline $6-10$ & 27 & 32.9 \\
\hline $11-15$ & 3 & 3.7 \\
\hline $16-20$ & 2 & 2.4 \\
\hline \multicolumn{3}{|l|}{$\begin{array}{l}\text { Age at first } \\
\text { pregnancy }\end{array}$} \\
\hline $13-16$ & 8 & 9.8 \\
\hline $17-20$ & 46 & 56.1 \\
\hline $21-24$ & 22 & 26.8 \\
\hline $25-28$ & 5 & 6.1 \\
\hline \multicolumn{3}{|l|}{$\begin{array}{l}\text { Total number } \\
\text { of pregnancy }\end{array}$} \\
\hline 1 & 16 & 19.5 \\
\hline 2 & 15 & 18.3 \\
\hline 3 & 24 & 29.3 \\
\hline 4 & 17 & 20.7 \\
\hline 5 & 4 & 4.9 \\
\hline 6 & 6 & 7.3 \\
\hline \multicolumn{3}{|l|}{ Birth interval } \\
\hline 0 & 16 & 19.5 \\
\hline 1 & 34 & 41.5 \\
\hline 2 & 22 & 26.8 \\
\hline 3 & 7 & 8.5 \\
\hline 4 & 2 & 2.4 \\
\hline 5 & 1 & 1.2 \\
\hline
\end{tabular}


Table 2: Family size and literacy status of study group.

\begin{tabular}{|llll|}
\hline $\begin{array}{l}\text { Family } \\
\text { size }\end{array}$ & \multicolumn{2}{l}{ Education Status } & Total \\
\hline$\leq 5$ & 12 & 38 & 50 \\
\hline $6-10$ & 6 & 21 & 27 \\
$11-15$ & 1 & 2 & 3 \\
$16-20$ & 0 & 2 & 2 \\
\hline Total & 19 & 63 & 82 \\
\hline
\end{tabular}

$\chi^{2}=0.049, \mathrm{df}=1, \mathrm{p}=0.82$

\section{Contraceptive practices}

A total of $32(39.0 \%)$ women in the study population didn't use any contraceptive. Remaining women were using some form of contraception (Tubectomy $=34.1 \%$, Condoms $=7.3 \%$, Copper-T $=11.1 \%$, OCPs $=7.3 \%$, Vasectomy $=1.2 \%$ ). Among all women, those who adopted tubectomy didn't use any spacing method till they completed their family (Table 3).

Table 3: Contraceptive practices among study group.

\begin{tabular}{|lll|}
\hline Family planning method & Number & Percentage \\
\hline No. contraceptives & 32 & 39.0 \\
\hline Tubectomy & 28 & 34.1 \\
\hline Condom & 6 & 7.3 \\
\hline Copper-T & 9 & 11.1 \\
\hline OCPs & 6 & 7.3 \\
\hline Vasectomy & 1 & 1.2 \\
\hline Total & 82 & 100.0 \\
\hline
\end{tabular}

\section{Knowledge of contraceptives}

Majority of study women had knowledge of contraceptives. Most of them, 30 (36.6\%) received information from doctors, while for remaining study women ,sources of information of contraceptives were, Health worker 12 (14.6\%), Media 6 (7.3\%), Relatives 19 (23.2\%), Friends 4 (4.9\%) Among all study participants, $11(13.4 \%)$ women had no knowledge of contraceptives. (Figure1).

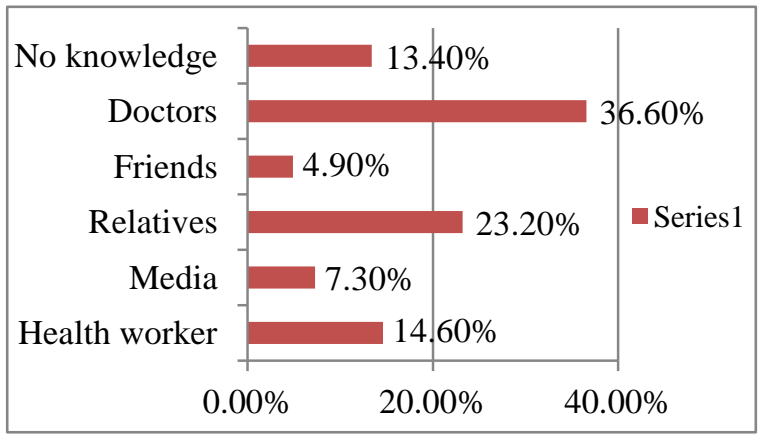

Figure 1: Source of information of contraceptives.
In present study, only $11(13.4 . \%)$ literate women, who were either, had secondary education or graduates were aware about emergency contraceptive, its brand name and also they had knowledge about how to use it (Table 4 and Table 5).

Table 4: Awareness of emergency contraception among study group.

\begin{tabular}{|lll|}
\hline Awareness & Number & Percentage \\
\hline No & 71 & 86.6 \\
\hline Yes & 11 & 13.4 \\
\hline Total & 82 & 100.0 \\
\hline
\end{tabular}

Table 5: Awareness of emergency contraception \& literacy of study group.

\begin{tabular}{|llll|}
\hline \multirow{2}{*}{$\begin{array}{c}\text { Awareness } \\
\text { about ECP }\end{array}$} & \multicolumn{2}{l|}{ Education Status } & Total \\
\hline No & 19 & 52 & 71 \\
\hline Yes & 0 & 11 & 11 \\
\hline Total & 19 & 63 & 82 \\
\hline
\end{tabular}

$\chi^{2}=2.47, \mathrm{df}=1, \mathrm{p}=0.06$

\section{DISCUSSION}

A total of 82 Muslim ever married women in a reproductive age (15-45 years) were interviewed. Majority of the women were literate, 63 (76.8\%), either they had primary or secondary education. Of all 58 $(70.7 \%)$ described their occupation as "housewife" while $24(29.3 \%)$ were "working". Similarly study by Farhana Irfan et al. ${ }^{3}$ showed that of all $83.8 \%$ were housewives while $16.3 \%$ were working women. In this study, majority $55(67.1 \%)$ of women belonged to a nuclear family. $50(61.0 \%)$ women had family size less than or equal to 5, while remaining women had family size more than 5 . Table 2 shows family size of the women which had no association with their literacy status.

A total of $32(39.0 \%)$ women in the study population didn't use any contraceptive. Remaining women were using some form of contraception (Tubectomy $=34.1 \%$, Condoms $=7.3 \%$, Copper- $\mathrm{T}=11.1 \%$, OCPs $=7.3 \%$, Vasectomy $=1.2 \%$ ). Among all women, those who adopted tubectomy, didn't use any spacing method till they completed their family. The main reasons for low contraceptive usage were that they wish to have more children, for male child, husband's disapproval for contraceptive use, for religious reasons, fear of adverse effects of contraceptives. In a study by M. M. Chandra Singh, ${ }^{4}$ contraceptive use was found to be only $8.6 \%$ and reasons for low contraceptive usage were fear of sideeffects, contraception failure, myths and beliefs such as impotency and weakness after vasectomy and religious restrictions etc. MZ Islam $^{5}$ reported that major part $(60.29 \%)$ of the women didn't use any contraceptive. A study conducted by Gaur DR et al. ${ }^{6}$ among rural Muslim 
women reported that $34.92 \%$ of subjects were using contraceptive methods.

Place of residence, education and religion are strongly related to both fertility and contraceptive use. More than half of married women with a high school education or above use contraceptives, compared to only one-third of illiterate women. ${ }^{7}$ In this study, socio-demographic factors like literacy status of women, income, education, type of family etc. didn't show any significant association with the use of contraceptive. Similarly study by M.M. Chandra Singh ${ }^{4}$ and Gaur DR et al. ${ }^{6}$ reported that Literacy status of the women did not show any significant association with contraceptive use.

Majority of study women had knowledge of contraceptives. Most of them, 30 (36.6\%) received information from doctors, while for remaining study women ,sources of information about contraceptives were, Health worker 12 (14.6\%), Media 6 (7.3\%), Relatives 19 (23.2\%), Friends 4 (4.9\%) Among all study participants, $11(13.4 \%)$ women had no knowledge of contraceptives. Similarly in a study by Farhana Irfan et $\mathrm{al}^{3}$ respondents who were aware of EC most commonly reported that they had first heard about EC from doctor/family planning provider $20(50 \%)$ or from a family member $8(20 \%)$. Other sources of information about EC were the magazine $6(15 \%)$, friend $5(12.5 \%)$ and internet $1(2.5)$.

The use of emergency contraceptive plays an important role in preventing unplanned pregnancies and the need for termination of pregnancies in these circumstances ${ }^{2}$ In present study, only $11(13.4 \%)$ literate women, who were either, had secondary education or graduates were aware about emergency contraceptive, its brand name and also they had knowledge about how to use it. Awareness of emergency contraception is quite low among both and women and men in every state. According to NFHS III, the knowledge about emergency contraception is $20 \%$ in men and $11 \%$ in women.

In present study despite $76.8 \%$ literacy among females, $32(39.0 \%)$ women didn't use any contraceptive and only $11(13.4 \%)$ were aware of Emergency Contraception. Awareness of EC was very low, but is almost similar to what has been reported in other studies. ${ }^{3,9,10}$ The lack of awareness about Emergency Contraception has been demonstrated both locally and worldwide, and even among those who know about this back-up contraceptive method it is still underutilized. ${ }^{9}$ A study by Farhan et $\mathrm{al}^{3}$ found that eighty-eight percent of women were not aware of EC. A study by Aruna Nigam et al. ${ }^{10}$ reported only 6 (2\%) women were aware of emergency contraceptive pills. Similarly study by Mehra R et al. ${ }^{11}$ reported only $1 \%$ women seeking abortion knew of emergency contraception.

\section{CONCLUSIONS}

Despite $76.8 \%$ literacy and $86.5 \%$ of awareness of the various methods of contraception, contraceptive practices were low among women.

$32(39.0 \%)$ women didn't use any contraceptive till they completed family.

There is a gap between awareness and practice. Awareness of emergency contraception is quite low among women (13.4\%). Emphasis has to be laid on education on planning and spacing children and reproductive contraceptive options, especially EC since all contraceptive methods can have potential failure, the use of EC plays an important role in preventing unplanned pregnancies.

\section{ACKNOWLEDGEMENTS}

Special thanks to the Medical Director, Dr S R Hegde for his encouragement. We are grateful to the Department of Community Medicine for the support and guidance. We are thankful to all the staff of Urban Health Center for their support during the study. We would also like to thank the women who participated in the study.

\section{Funding: No funding sources \\ Conflict of interest: None declared \\ Ethical approval: Not required}

\section{REFERENCES}

1. NFHS-3, ministry of health and family welfare, Government of India, International Institute of Population sciences Deonar, Mumbai-400088. 200506(1). Available at: http://www.measuredhs.com/pubs/pdf/FRIND3/00Fr ontMatter00.pdf. Accessed September 2007.

2. Hang-Wun Raymond Li; Sue Seen-Tsing Lo; Ernest Hung-Yu Ng, Pak-Chung Ho. An Update on Emergency Contraception. JPOG. 2011August:3049.

3. Farhana Irfan, Sajid Ali, Syed Irfan Karim, Saman Hashmi, Syed Arif Knowledge of emergency contraception among women of childbearing age at a teaching hospital of Karachi, JPMA. 2009;59:235.

4. M. M. Chandra Singh, A. Khokar, D. Pagare, N. Sharma and M. Mehra. A study of contraceptive use among ever-married Muslim women in an urban slum of Delhi. Health and Population-Perspectives and Issues. 2003;26(1):10-15.

5. MZ Islam, H Shaila, Z Farzana Reproductive health profile of married women: experience from a rural community of Bangladesh. Bangladesh Journal of Medical Science 2011;10(4):252-6.

6. Gaur DR, Goel MK, Goel M. Contraceptive practices and related factors among females in predominantly rural Muslim area of North India. The 
Internet $\mathbf{J}$ of World health and Societal Politics. 2008;5(1):5.

7. Ashok Kumar, M.E. Khan. Health status of women in India: Evidences from National Family Health Survey-3 (2005-06) and future outlook. Population Council Research and Practice in Social Sciences Kumar \& Khan. 2010August;6(2):1-21.

8. NFHS-3, ministry of health and family welfare, Government Of India, International Institute of Population sciences Deonar, Mumbai-400088. 200506(1). Available at: http://www.measuredhs.com/pubs/pdf/FRIND3/00Fr ontMatter00.pdf. Accessed September 2007.

9. A profile of youth in India. National Family Health Survey (NFHS-3) India. International Institute for Population Sciences. Deonar. Mumbai. 2005-06(1). Available at: http://www.measuredhs.com/pubs/pdf/OD59/OD59. pdf. Accessed August 2009.
10. Westley E, Glasier A. Emergency contraception; dispelling the myths and misconceptions. Bull World Health Organ. 2010;88:243.

11. Aruna Nigam, Neha Maheshwari, Anupam Prakash. Knowledge of Emergency contraception and contraceptive practice: Representative study from rural Uttar Pradesh. Indian Journal of Community Medicine. 2010July;35(3):449-50.

12. Mehra R, Goel P, Dua D, Huria A. Knowledge of emergency contraception among women coming for induced abortion. J Obstet Gynaecol India. 2006;56:233-5.

DOI: $10.5455 / 2320-1770 . i j r \operatorname{cog} 20140314$

Cite this article as: Ade AD, Patil R. Contraceptive practices and awareness of emergency contraception among Muslim women of urban slum of Raichur, Karnataka. Int J Reprod Contracept Obstet Gynecol 2014;3:70-4. 